\title{
Stimulation of Suicidal Erythrocyte Death by the CDC25 Inhibitor NSC-95397
}

\author{
Mohamed Jemaàa Morena Mischitellia,b Myriam Fezaia Mustafa Almasrya \\ Caterina Faggiob Florian Lang ${ }^{a, c}$ \\ aDepartment of Cardiology, Vascular Medicine and Physiology, Eberhard-Karls-University of Tuebingen, \\ Tuebingen, Germany; ${ }^{b}$ Department of Chemical, Biological, Pharmaceutical and Environmental \\ Sciences-University of Messina Viale Ferdinando Stagno d'Alcontres, S. Agata-Messina, Italy; \\ 'Department of Molecular Medicine II, Medical Faculty, Heinrich Heine University, Düsseldorf, Germany
}

\section{Key Words}

Phosphatidylserine $\cdot$ Cell volume $•$ Eryptosis $•$ Calcium $・$ NSC-95397 $•$ Staurosporine $・$ Necrostatin

\begin{abstract}
Background/Aims: The CDC25B inhibitor NSC-95397 triggers apoptosis of tumor cells and is thus considered for the treatment of malignancy. The substance is effective in part by modification of gene expression. Similar to apoptosis of nucleated cells erythrocytes may undergo eryptosis, the suicidal erythrocyte death characterized by cell shrinkage and cell membrane scrambling with phosphatidylserine translocation to the erythrocyte surface. Eryptosis may be triggered by increase of cytosolic $\mathrm{Ca}^{2+}$ activity $\left(\left[\mathrm{Ca}^{2+}\right]_{\mathrm{i}}\right)$, oxidative stress, ceramide, as well as activation of protein kinases. The present study explored, whether NSC95397 induces eryptosis and, if so, to shed some light on the mechanisms involved. Methods: Phosphatidylserine exposure at the cell surface was estimated from annexin-V-binding, cell volume from forward scatter, $\left[\mathrm{Ca}^{2+}\right]_{\mathrm{i}}$ from Fluo3-fluorescence, ROS formation from DCFDA dependent fluorescence, and ceramide abundance utilizing specific antibodies. Results: A 48 hours exposure of human erythrocytes to NSC-95397 significantly increased the percentage of annexin-V-binding cells $(\geq 1 \mu \mathrm{M})$, significantly decreased forward scatter $(\geq 2.5 \mu \mathrm{M})$, and significantly increased Fluo3-fluorescence $(\geq 1 \mu \mathrm{M})$, DCFDA fluorescence $(5 \mu \mathrm{M})$ and ceramide abundance $(\geq 5 \mu \mathrm{M})$. The effect of NSC-95397 $(5 \mu \mathrm{M})$ on annexin-V-binding was slightly, but significantly blunted by removal of extracellular $\mathrm{Ca}^{2+}$ and by addition of the protein kinase C inhibitor staurosporine $(1 \mu \mathrm{M})$. Conclusions: NSC-95397 triggers cell shrinkage and phospholipid scrambling of the erythrocyte cell membrane, an effect in part requiring entry of $\mathrm{Ca}^{2+}$ and activation of staurosporine sensitive kinase(s).
\end{abstract}

\section{Introduction}

NSC95397 (2,3-bis-[(2-hydroxyethyl)thio]-1,4-naphthoquinone), a dual-specificity phosphatase cell division cycle 25 B (CDC25B) inhibitor [1-10], counteracts inflammation

Mohamed Jemaà and Florian Lang
Department of Physiology, Cardiology and Cardiovascular Medicine, University of Tuebingen, Gmelinstr. 5, 72076 Tuebingen (Germany)

Tel. +49 7071 29-72194, Fax +49 7071 29-5618, E-Mail florian.lang@uni-tuebingen.de

\section{KARGER}


[10] and cancer [10]. NSC95397 is in part effective by inhibition of the kinases AKT, IKK $\alpha / \beta$, MKK7, and TBK1 [10], inhibition of the $\mathrm{Ca}^{2+}$ binding protein S100A4 [11, 12], suppression of the transcription factors NF- $\mathrm{BB}$ (p65) and AP-1 (c-Fos/c-Jun) [10] and downregulation of tumor necrosis factor (TNF)- $\alpha$, inducible NO synthase (iNOS), cyclooxygenase (COX)-2, and interferon (IFN)- $\beta$ expression [10]. NSC95397 influences transcription by disrupting the interaction between Carboxyl-terminal binding protein (CtBP) and its partner proteins [13]. NSC95397 interferes with transcription of viral proteins [14] and decreases the expression of the epithelial $\mathrm{Na}^{+}$channel ENaC [15]. NSC95397 triggers apoptosis of diverse tumor cells and is thus considered for the treatment of malignancy $[6,16,17]$.

Even though lacking nuclei and mitochondria, key regulators of apoptosis, erythrocytes may enter suicidal death or eryptosis [18], which is characterized by cell shrinkage [19] and cell membrane scrambling with breakdown of phospholipid asymmetry of the cell membrane apparent from phosphatidylserine exposure at the cell surface [18]. Eryptosis may be triggered by increase of cytosolic $\mathrm{Ca}^{2+}$ activity $\left(\left[\mathrm{Ca}^{2+}\right]_{\mathrm{i}}\right)[18]$, ceramide [20], oxidative stress [18], energy depletion [18], activated caspases [18, 21, 22], as well as stimulation of casein kinase $1 \alpha$, Janus-activated kinase JAK3, protein kinase C, and/or p38 kinase [18]. Eryptosis is inhibited by activation of AMP activated kinase AMPK, cGMP-dependent protein kinase, PAK2 kinase, and sorafenib/sunitinib sensitive kinases [18]. Eryptosis could be elicited by a wide variety of xenobiotics [18, 23-58].

The present study explored, whether and how NSC-95397 stimulates eryptosis. To this end, erythrocytes from healthy volunteers were treated with NSC-95397 and phosphatidylserine surface abundance, cell volume, $\left[\mathrm{Ca}^{2+}\right]_{i}$, ROS formation, and ceramide abundance determined by flow cytometry.

\section{Materials and Methods}

Erythrocytes, solutions and chemicals

Fresh Li-Heparin-anticoagulated blood samples were kindly provided by the blood bank of the University of Tübingen. The study is approved by the ethics committee of the University of Tübingen $(184 / 2003 \mathrm{~V})$. The blood was centrifuged at $120 \mathrm{~g}$ for $20 \mathrm{~min}$ at $21^{\circ} \mathrm{C}$ and the platelets and leukocytes-containing supernatant was disposed. Erythrocytes were incubated in vitro at a hematocrit of $0.4 \%$ in Ringer solution containing (in mM) $125 \mathrm{NaCl}, 5 \mathrm{KCl}, 1 \mathrm{MgSO}_{4}$, $32 \mathrm{~N}$-2-hydroxyethylpiperazine-N-2-ethanesulfonic acid (HEPES; pH 7.4), 5 glucose, $1 \mathrm{CaCl}_{2}$, at $37^{\circ} \mathrm{C}$ for 48 hours. Where indicated, erythrocytes were exposed for 48 hours to NSC-95397 (MedChem Express, Princeton, USA), $\mathrm{Ca}^{2+}$-free solution without or with addition of $\mathrm{Ca}^{2+}$ chelator 1,2-Bis(2aminophenoxy)ethane- $\mathrm{N}, \mathrm{N}, \mathrm{N}^{\prime}, \mathrm{N}^{\prime}$-tetraacetic acid tetrakis(acetoxymethyl ester) BAPTA-AM (Thermo Fisher Scientific, Darmstadt, Germany), necroptosis inhibitor necrostatin-1 (Sigma, Schnelldorf, Germany), p38 kinase inhibitor SB 203580 (Tocris bioscience, Bristol, UK), protein kinase C inhibitor staurosporine (Sigma Aldrich, Hamburg, Germany), casein kinase inhibitor D4476 (Sigma Aldrich, Hamburg, Germany), and pan-caspase inhibitor zVAD (Tocris bioscience, Bristol, UK).

\section{Annexin-V-binding and forward scatter}

After incubation under the respective experimental condition, a $150 \mu \mathrm{l}$ cell suspension was washed in Ringer solution containing $5 \mathrm{mM} \mathrm{CaCl}_{2}$ and then stained with Annexin-V-FITC (1:200 dilution; ImmunoTools, Friesoythe, Germany) in this solution at $37^{\circ} \mathrm{C}$ for $15 \mathrm{~min}$ under protection from light. The annexin-Vabundance at the erythrocyte surface was subsequently determined on a FACS Calibur (BD, Heidelberg, Germany). Annexin-V-binding was measured with an excitation wavelength of $488 \mathrm{~nm}$ and an emission wavelength of $530 \mathrm{~nm}$. A marker (M1) was placed to set an arbitrary threshold between annexin-V-binding cells and control cells. The same threshold was used for untreated and NSC-95397 treated erythrocytes. A dot plot of forward scatter (FSC) vs. side scatter (SSC) was set to linear scale for both parameters. The threshold of forward scatter was set at the default value of " 52 ".

\section{KARGER}




\section{Cellular Physiology Cell Physiol Biochem 2016;40:597-607

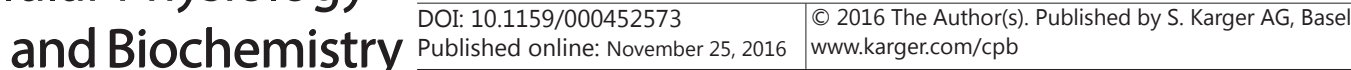 \\ Jemaà et al.: NSC-95397-Induced Eryptosis}

Hemolysis

For the determination of hemolysis, the samples were centrifuged (10 min at $2000 \mathrm{rpm}$, room temperature) after incubation under the respective experimental conditions and the supernatants were harvested. As a measure of hemolysis, the hemoglobin $(\mathrm{Hb})$ concentration of the supernatant was determined photometrically at $405 \mathrm{~nm}$. The absorption of the supernatant of erythrocytes lysed in distilled water was defined as $100 \%$ hemolysis.

Intracellular $\mathrm{Ca}^{2+}$

After incubation, erythrocytes were washed in Ringer solution and loaded with Fluo-3/AM (Biotium, Hayward, USA) in Ringer solution containing $5 \mathrm{mM} \mathrm{CaCl}_{2}$ and $5 \mu \mathrm{M}$ Fluo-3/AM. The cells were incubated at $37^{\circ} \mathrm{C}$ for $30 \mathrm{~min}$. $\mathrm{Ca}^{2+}$-dependent fluorescence intensity was measured with an excitation wavelength of 488 $\mathrm{nm}$ and an emission wavelength of $530 \mathrm{~nm}$ on a FACS Calibur.

Reactive oxygen species (ROS)

ROS abundance was determined utilizing 2',7'-dichlorodihydrofluorescein diacetate (DCFDA). After incubation, a $150 \mu$ l suspension of erythrocytes was washed in Ringer solution and stained with DCFDA (Sigma, Schnelldorf, Germany) in Ringer solution containing DCFDA at a final concentration of $10 \mu \mathrm{M}$. Erythrocytes were incubated at $37^{\circ} \mathrm{C}$ for $30 \mathrm{~min}$ in the dark and washed two times in Ringer solution. The DCFDA-loaded erythrocytes were resuspended in $200 \mu \mathrm{l}$ Ringer solution and ROS-dependent fluorescence intensity was measured at an excitation wavelength of $488 \mathrm{~nm}$ and an emission wavelength of $530 \mathrm{~nm}$ on a FACS Calibur (BD).

\section{Ceramide abundance}

For the determination of ceramide, a monoclonal antibody-based assay was used. To this end, cells were stained for 1 hour at $37^{\circ} \mathrm{C}$ with $1 \mu \mathrm{g} / \mathrm{ml}$ anti ceramide antibody (clone MID 15B4, Alexis, Grünberg, Germany) in PBS containing $0.1 \%$ bovine serum albumin (BSA) at a dilution of 1:10. The samples were washed twice with PBS-BSA. The cells were stained for 30 minutes with polyclonal fluorescein isothiocyanate (FITC) conjugated goat anti-mouse IgG and IgM specific antibody (Pharmingen, Hamburg, Germany) diluted 1:50 in PBS-BSA. Unbound secondary antibody was removed by repeated washing with PBS-BSA. The samples were analyzed by flow cytometric analysis with an excitation wavelength of $488 \mathrm{~nm}$ and an emission wavelength of $530 \mathrm{~nm}$. As a control, secondary antibody alone was used.

\section{Statistics}

Data are expressed as arithmetic means \pm SEM. As indicated in the Figure legends, statistical analysis was made using ANOVA with Tukey's test as post-test and $t$ test as appropriate. $\mathrm{n}$ denotes the number of different erythrocyte specimens studied. Since different erythrocyte specimens used in distinct experiments are differently susceptible to triggers of eryptosis, the same erythrocyte specimens have been used for control and experimental conditions.

\section{Results}

The present study explored whether NSC-95397 stimulates eryptosis, the suicidal erythrocyte death characterized by cell shrinkage and phospholipid scrambling of the cell membrane with phosphatidylserine translocation to the cell surface.

Erythrocyte volume was estimated from forward scatter which was determined utilizing flow cytometry. Prior to measurements, the erythrocytes were incubated for 48 hours in Ringer solution without or with NSC-95397 $(0.5-5 \mu \mathrm{M})$. As illustrated in Fig. 1A,B, NSC95397 decreased erythrocyte forward scatter, an effect reaching statistical significance at $2.5 \mu$ M NSC-95397 concentration. NSC-95397 further increased the percentage of shrunken erythrocytes, an effect reaching statistical significance at $0.5 \mu \mathrm{M}$ NSC-95397 concentration (Fig. 1C). As shown in Fig. 1D, 0.5 and $1 \mu$ M NSC-95397 increased in addition significantly the percentage of swollen erythrocytes. 
Fig. 1. Effect of NSC-95397 on erythrocyte forward scatter. A. Original histograms of forward scatter of erythrocytes following exposure for 48 hours to Ringer solution without (grey area) and with (black line) presence of $5 \mu \mathrm{M}$ NSC-95397. B. Arithmetic means \pm SEM ( $n=9$ ) of the erythrocyte forward scatter (FSC) following incubation for 48 hours to Ringer solution without (white bar) or with (black bars) NSC-95397 (0.5 - 5 $\mu \mathrm{M})$. C,D. Percentage of erythrocytes with (C) FSC $<200$ or (D) FSC $>800$ following incubation for 48 hours to Ringer solution without (white bar) or with (black bars) NSC-95397 (0.5 - $5 \mu \mathrm{M}) . *(<0.05)$, $* * *(\mathrm{p}<0.001)$ indicates significant difference from the absence of NSC-95397 (ANOVA).
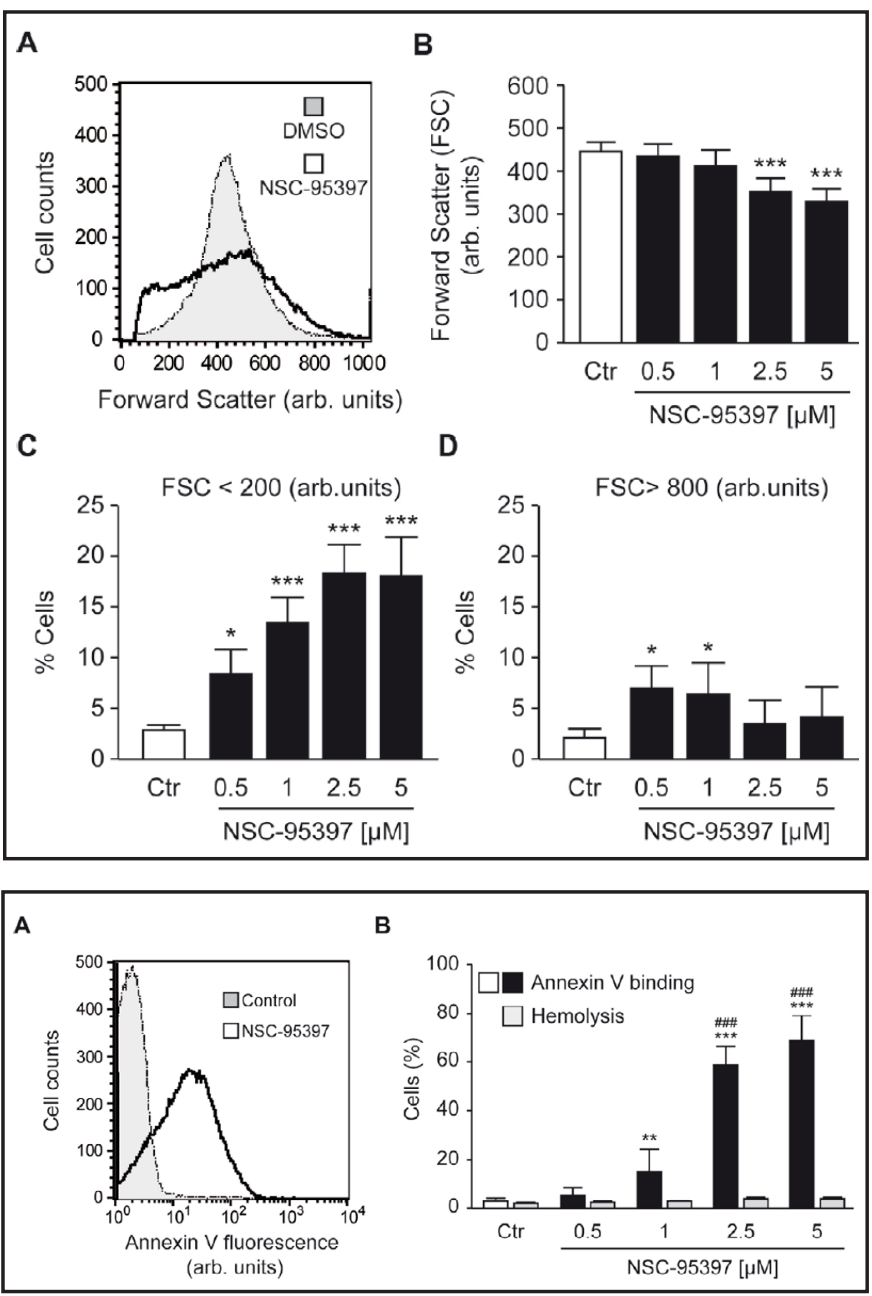

A

C

Fig. 2. Effect of NSC-95397 on phosphatidylserine exposure. A. Original histograms of annexin-V-binding of erythrocytes following exposure for 48 hours to Ringer solution without (grey area) and with (black line) presence of $5 \mu \mathrm{M}$ NSC-95397. B. Arithmetic means \pm SEM ( $n=9$ ) of erythrocyte annexin-V-binding following incubation for 48 hours to Ringer solution without (white bar) or

with (black bars) NSC-95397 $(0.5-5 \mu \mathrm{M}) .{ }^{* *}(\mathrm{p}<0.01),{ }^{* * *}(\mathrm{p}<0.001)$ indicates significant difference from the absence of NSC-95397 (ANOVA). ${ }^{\# \#(p<0.001)}$ indicates significant difference between hemolysis and eryptotic death (ANOVA).

Fig. 3. Effect of NSC-95397 on cytosolic A $\mathrm{Ca}^{2+}$ activity. A. Original histograms of Fluo3 fluorescence in erythrocytes following exposure for 48 hours to Ringer solution without (grey area) and with (black line) presence of $5 \mu \mathrm{M}$ NSC95397. B. Arithmetic means \pm SEM ( $\mathrm{n}=$ 9) of Fluo3 fluorescence in erythrocytes following incubation for 48 hours to Ringer solution without (white bar) or

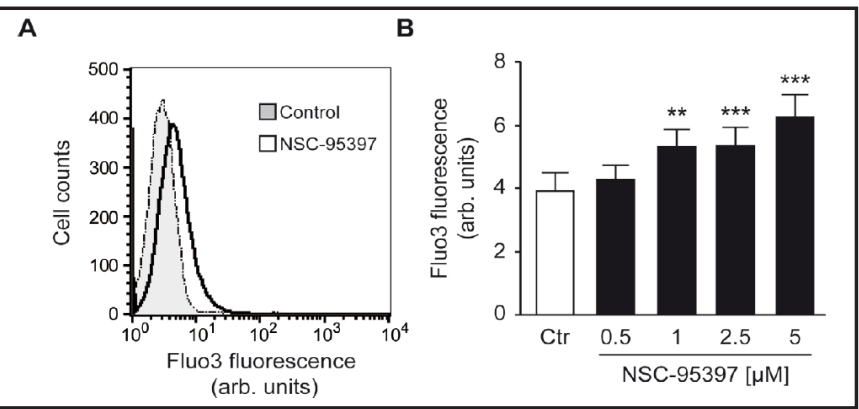
with (black bars) NSC-95397 $(0.5-5 \mu \mathrm{M}) .{ }^{* *}(\mathrm{p}<0.01),{ }^{* * *}(\mathrm{p}<0.001)$ indicates significant difference from the absence of NSC-95397 (ANOVA).

Phosphatidylserine exposing erythrocytes were identified utilizing annexin-V-binding, as determined by flow cytometry. Prior to measurements, the erythrocytes were again incubated for 48 hours in Ringer solution without or with NSC-95397 (0.5-5 $\mu \mathrm{M})$. As shown in Fig. 2, a 48 hours exposure to NSC-95397 increased the percentage of phosphatidylserine exposing erythrocytes, an effect reaching statistical significance at $1.0 \mu \mathrm{M}$ NSC-95397. 
Fig. 4. $\mathrm{Ca}^{2+}$ sensitivity of NSC-95397-induced phosphatidylserine exposure. A,B. Original histograms of annexin-V-binding of erythrocytes following exposure for 48 hours to Ringer solution without (grey areas) and with (black lines) NSC-95397 (5 $\mu \mathrm{M})$ in the presence (A) and absence (B) of extracellular $\mathrm{Ca}^{2+}$. C. Arithmetic means \pm SEM $(n=9)$ of annexin-V-binding of erythrocytes after a 48 hours treatment with Ringer solution without (white bars) or with (black bars) NSC-95397 (5 $\mu \mathrm{M})$ in the presence (left bars, $+\mathrm{Ca}^{2+}$ ) and absence (right bars, $\left.-\mathrm{Ca}^{2+}\right)$ of $\mathrm{Ca}^{2+}$. ${ }^{* * *}(\mathrm{p}<0.001)$ indicates significant difference from the absence of NSC-95397, \# $(p<0.05)$ indicates significant difference from the presence of $\mathrm{Ca}^{2+}$ (ANOVA).

Fig. 5. $\mathrm{Ca}^{2+}$ and BAPTA-AM sensitivity of NSC-95397-induced phosphatidylserine exposure. A,B. Original histograms of annexin-V-binding of erythrocytes following exposure for 48 hours to Ringer solution without (grey areas) and with (black lines) NSC-95397 (5 $\mu \mathrm{M})$ in the absence (A) and presence (B) of $\mathrm{Ca}^{2+}$ chelator BAPTA-AM $(50 \mu \mathrm{M})$. C. Arithmetic means \pm SEM $(n=10)$ of annexin-V-binding of erythrocytes after a 48 hours treatment with Ringer solution without (white bars) or with (black bars) NSC-95397 (5 $\mu \mathrm{M})$ in the absence (left bars, -BAPTA-AM) and presence (right bars, +BAPTA-AM) of $\mathrm{Ca}^{2+}$ chelator BAPTA-AM. ${ }^{* * *}(\mathrm{p}<0.001)$ indicates significant difference from the absence of NSC-95397, " $(p<0.05)$ indicates significant difference from the absence of BAPTA-AM (ANOVA).
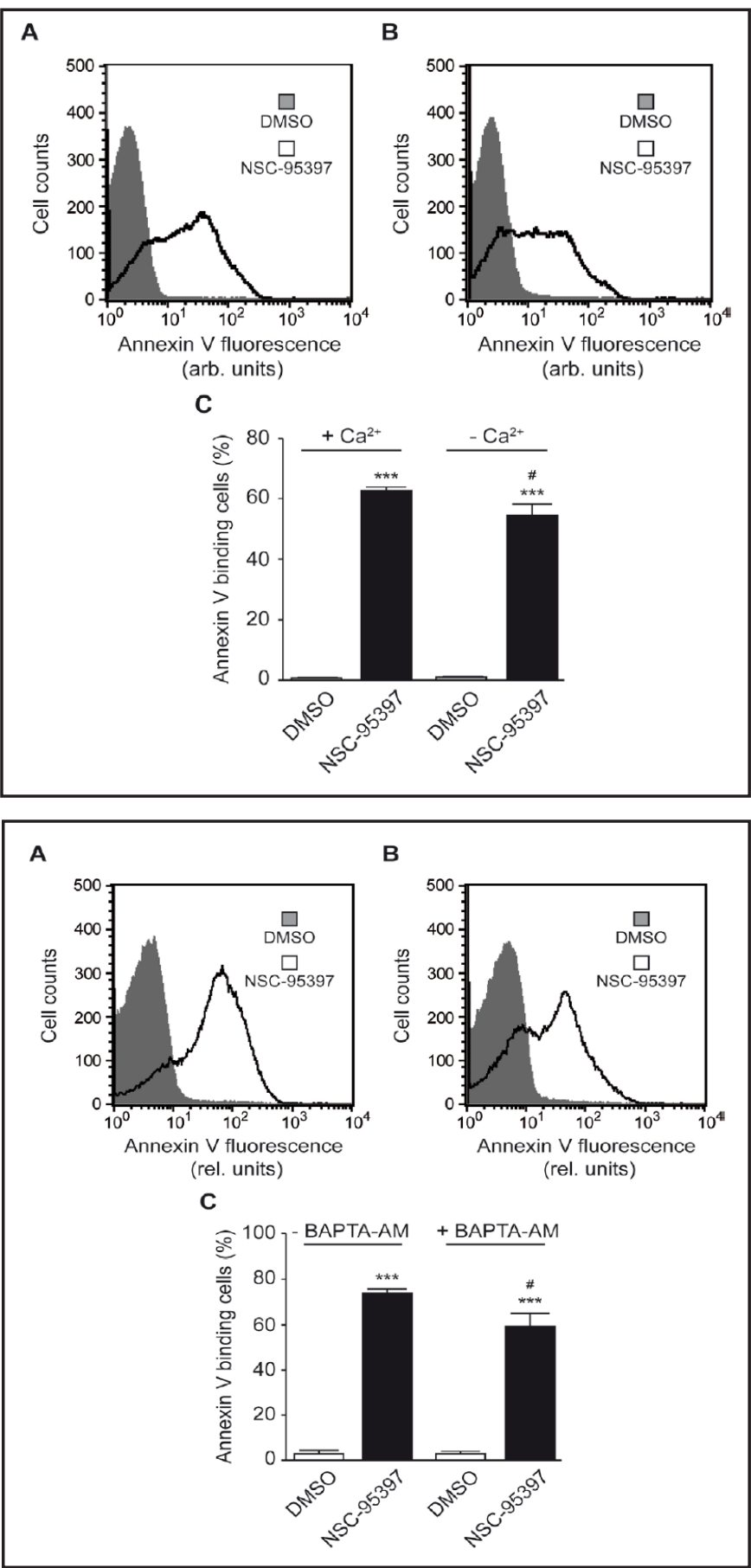

Following a 48 hours incubation, the percentage of hemolytic erythrocytes was similarly low in the absence of NSC-95397 (1.7 $\pm 0.2 \%, \mathrm{n}=9)$ and in the presence of $0.5 \mu \mathrm{M}(2.1 \pm 0.1$ $\%, \mathrm{n}=9), 1 \mu \mathrm{M}(2.5 \pm 0.2 \%, \mathrm{n}=9), 2.5 \mu \mathrm{M}(3.7 \pm 0.3 \%, \mathrm{n}=9)$ and $5 \mu \mathrm{M}(3.8 \pm 0.5 \%, \mathrm{n}=9)$ NSC-95397.

Fluo3 fluorescence was taken as a measure of cytosolic $\mathrm{Ca}^{2+}$ activity $\left(\left[\mathrm{Ca}^{2+}\right]_{\mathrm{j}}\right)$. As illustrated in Fig. 3, following a 48 hours incubation the Fluo3 fluorescence was higher in the presence than in the absence of NSC-95397, a difference reaching statistical significance at $1.0 \mu \mathrm{M}$ NSC-95397. 
Fig. 6. Effect of NSC-95397 on ROS formation. A. Original histogram of DCF fluorescence in erythrocytes following exposure for 48 hours to Ringer solution without (grey area) and with (black line) presence of NSC-95397 $(5 \mu \mathrm{M})$. B. Arithmetic means \pm SEM $(n=9)$ of the DCF fluorescence (arbitrary units) in erythrocytes exposed for 48 hours to Ringer solution without (white bar) or with (black bar) NSC-95397 $(5 \mu \mathrm{M}) . *(\mathrm{p}<0.05)$ indicates

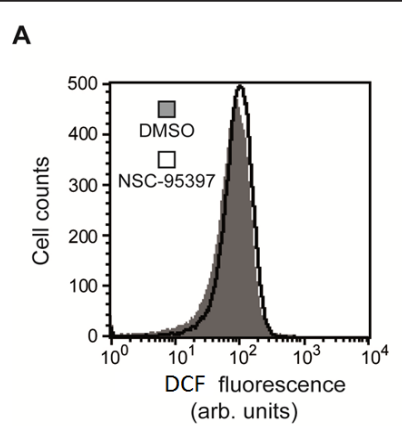

B

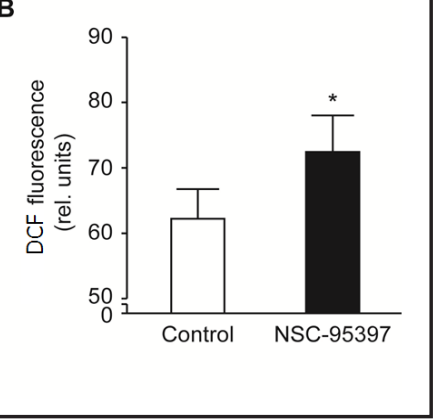
significant difference from the absence of NSC-95397 (ANOVA).

Fig. 7. Effect of NSC-95397 on ceramide abundance at the erythrocyte surface. A. Original histogram of ceramide abundance in erythrocytes following exposure for 48 hours to Ringer solution without (grey area) and with (black line) presence of NSC-95397 $(5 \mu \mathrm{M})$. B. Arithmetic means \pm SEM ( $n=9)$ of the ceramide abundance (arbitrary units) in erythrocytes exposed for 48 hours to Ringer solution without (white bar) or with (black bar) NSC-

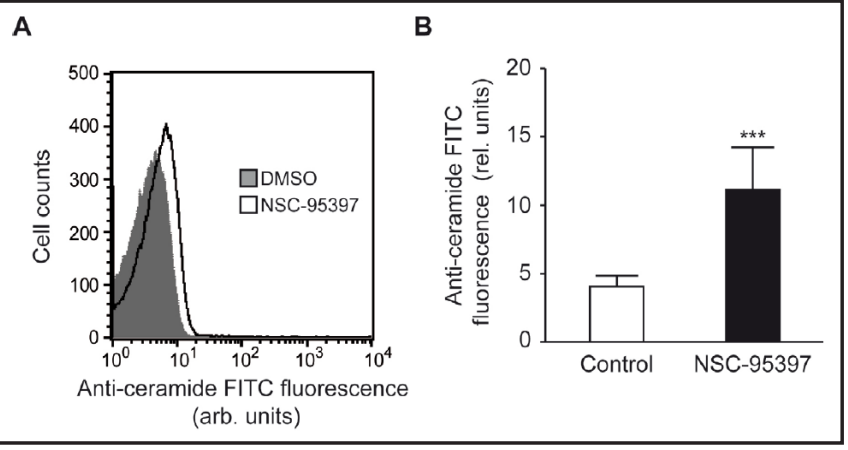
$95397(5 \mu \mathrm{M}) .{ }^{* * *}(\mathrm{p}<0.001)$ indicates significant difference from the absence of NSC-95397 (ANOVA).

A next series of experiments explored whether the NSC-95397-induced annexin-Vbinding required entry of extracellular $\mathrm{Ca}^{2+}$. To this end, erythrocytes were incubated for 48 hours in the absence or presence of $5 \mu \mathrm{M}$ NSC-95397 in the presence or nominal absence of extracellular $\mathrm{Ca}^{2+}$. As illustrated in Fig. 4, removal of extracellular $\mathrm{Ca}^{2+}$ slightly but significantly blunted the effect of NSC-95397 on annexin-V-binding. However, even in the absence of extracellular $\mathrm{Ca}^{2+}$, NSC-95397 significantly increased the percentage of annexin-V-binding erythrocytes. Thus, NSC-95397-induced annexin-V-binding was only in small part triggered by entry of extracellular $\mathrm{Ca}^{2+}$. As illustrated in Fig. 5, similar observations were made, when in nominally $\mathrm{Ca}^{2+}$ free solutions $\mathrm{Ca}^{2+}$ was in addition bound to $\mathrm{Ca}^{2+}$ chelator BAPTA-AM.

Eryptosis is further stimulated by oxidative stress. Reactive oxygen species (ROS) was thus quantified utilizing $2^{\prime}, 7^{\prime}$-dichlorodihydrofluorescein (DCF) diacetate. As illustrated in Fig. 6, following a 48 hours incubation the DCF fluorescence was significantly higher in the presence than in the absence of $5 \mu$ M NSC-95397. Thus, NSC-95397 induced oxidative stress.

A further stimulator of eryptosis is ceramide. Ceramide abundance at the erythrocyte surface was thus quantified utilizing specific antibodies. As illustrated in Fig. 7, following a 48 hours incubation the ceramide abundance was significantly higher in the presence than in the absence of $5 \mu$ M NSC-95397. Thus, NSC-95397 enhanced the ceramide abundance.

As illustrated in Fig. 8, the effect of NSC-95397 on annexin-V-binding was insensitive to necroptosis-inhibitor necrostatin $(100 \mu \mathrm{M})$, casein kinase inhibitor D4476 (10 $\mu \mathrm{M})$, pancaspase inhibitor zVAD $(10 \mu \mathrm{M})$, and p38 kinase inhibitor SB203580 $(2 \mu \mathrm{M})$.

To explore, whether the effects of NSC-95397 involved protein kinase C activity, the influence of NSC-95397 on annexin-V-binding was tested in the presence of protein kinase C inhibitor staurosporine $(1 \mu \mathrm{M})$. Erythrocytes were incubated for 48 hours in the absence or presence of $5 \mu \mathrm{M}$ NSC-95397 in the absence and presence of staurosporine. As illustrated in Fig. 9, addition of staurosporine slightly but significantly blunted the effect of NSC-95397 on annexin-V-binding. However, even in the presence of staurosporine, NSC-95397 significantly 
Fig. 8. Insensitivity of NSC-95397-induced phosphatidylserine exposure to Necrostatin, D4476, zVAD, and SB203580. Arithmetic means \pm SEM $(n=10)$ of annexin-V-binding of erythrocytes after a 48 hours treatment with Ringer solution without (white bars) or with (black bars) NSC-95397 (5 $\mu \mathrm{M})$ in the absence (DMSO) and presence of 100 $\mu \mathrm{M}$ necrostatin, $10 \mu \mathrm{M}$ D4476, $10 \mu \mathrm{M}$ zVAD, or $2 \mu \mathrm{M}$ SB203580. ${ }^{* * *}(\mathrm{p}<0.001)$ indicates significant difference from the absence of NSC-95397 (ANOVA).

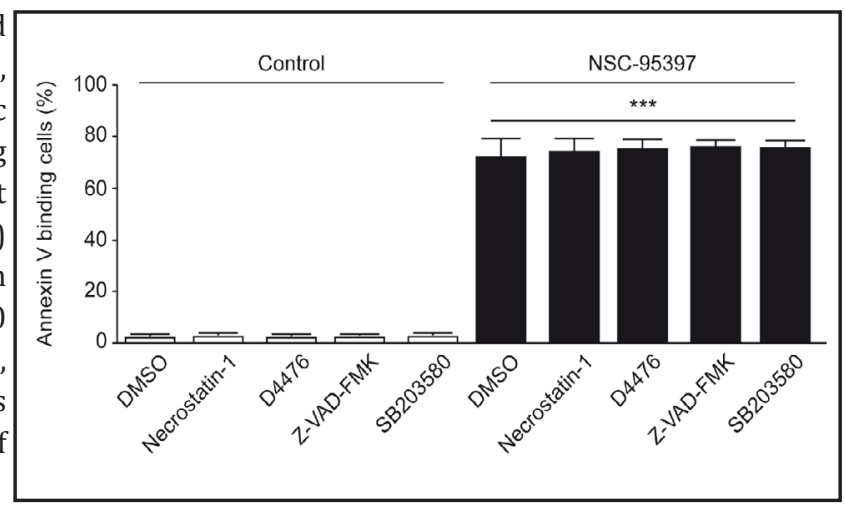

Fig. 9. Sensitivity of NSC-95397-induced phosphatidylserine exposure to protein kinase $\mathrm{C}$ inhibition. A,B. Original histograms of annexin-V-binding of erythrocytes following exposure for 48 hours to Ringer solution without (grey areas) and with (black lines) NSC-95397 $(5 \mu \mathrm{M})$ in the absence (A) and presence $(\mathrm{B})$ of protein kinase $\mathrm{C}$ inhibitor (PKC i) staurosporine $(1 \mu \mathrm{M})$. C. Arithmetic means \pm SEM $(n=9)$ of annexin-V-binding of erythrocytes after a 48 hours treatment with Ringer solution without (white bars) or with (black bars) NSC-95397 $(5 \mu \mathrm{M})$ in the absence (left bars, -PKC i) and presence (right bars, +PKC i) of protein kinase C inhibitor staurosporine (1 $\mu \mathrm{M}) .{ }^{* * *}(\mathrm{p}<0.001)$ indicates significant difference from the absence of NSC95397, $\#(\mathrm{p}<0.05)$ indicates significant difference from the absence of PKC i staurosporine (ANOVA).

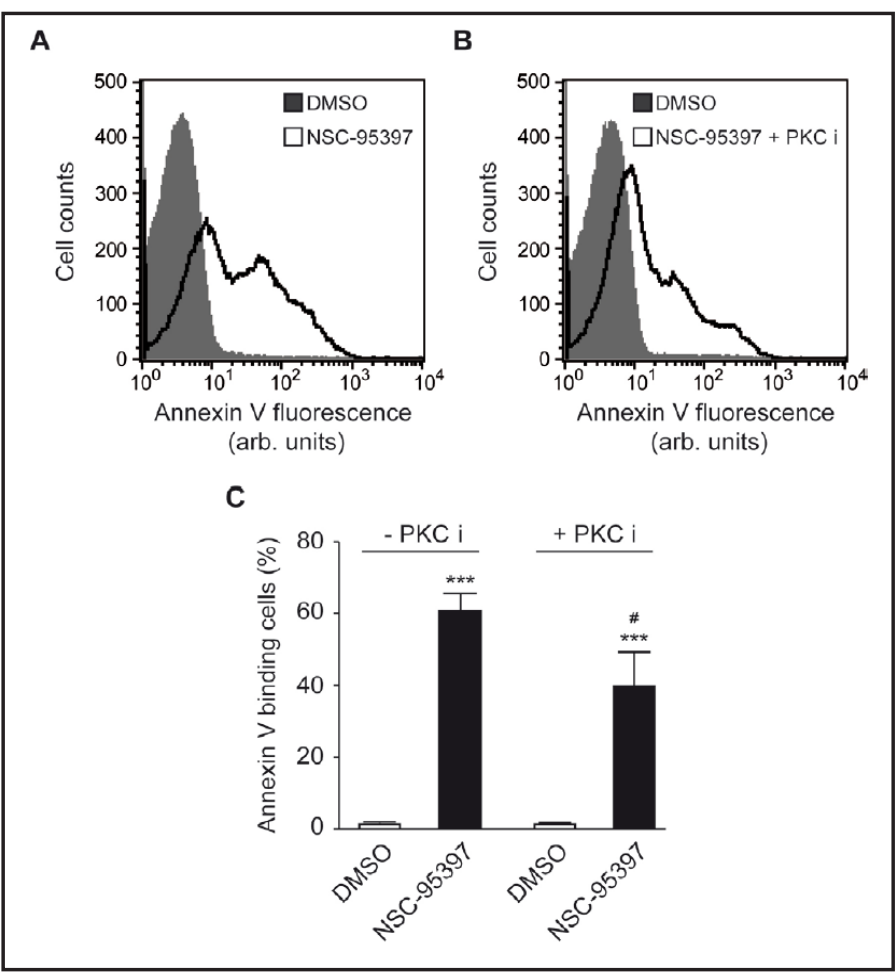

increased the percentage of annexin-V-binding erythrocytes. Thus, NSC-95397-induced annexin-V-binding was only in small part dependent on protein kinase $\mathrm{C}$ activity.

NSC-95397 decreased the average forward scatter to a similar extent in the absence (from $492.8 \pm 34.3$ to $379 \pm 42.4, \mathrm{n}=9$ ) and in the presence (from $463.3 \pm 18.7$ to $414 \pm 38.4$, $\mathrm{n}=9)$ of staurosporine $(1 \mu \mathrm{M})$.

\section{Discussion}

The present observations reveal that the CDC25B inhibitor NSC-95397 triggers suicidal erythrocyte death or eryptosis. Treatment of erythrocytes drawn from healthy volunteers with NSC-95397 is followed by cell shrinkage and cell membrane scrambling with phosphatidylserine translocation to the erythrocyte surface.

The effect of NSC-95397 on cell membrane scrambling was paralleled by increase of cytosolic $\mathrm{Ca}^{2+}$ activity $\left(\left[\mathrm{Ca}^{2+}\right]_{\mathrm{i}}\right)$ and was slightly, but significantly blunted by removal of extracellular $\mathrm{Ca}^{2+}$. However, even in the nominal absence of extracellular of $\mathrm{Ca}^{2+} \mathrm{NSC}-95397$ 
treatment was followed by a significant stimulation of eryptosis, an observation pointing to involvement of $\mathrm{Ca}^{2+}$ independent mechanisms. Those mechanisms apparently include oxidative stress, as NSC-95397 increased the DCF fluorescence. Oxidative stress is a powerful stimulator of eryptosis [18]. NSC-95397 further increased the erythrocyte surface abundance of ceramide, which could sensitize erythocytes for the scrambling effect of $\mathrm{Ca}^{2+}$ [18]. The effect of NSC-95397 may further involve activation of staurosporine sensitive kinases such as protein kinase C. Protein kinase $\mathrm{C}$ is a strong stimulator of eryptosis [18].

NSC-95397 did not significantly modify hemolysis. Eryptosis allows the clearance of defective erythrocytes from circulating blood prior to hemolysis [18]. To the extent that eryptosis precedes hemolysis, it prevents the release of hemoglobin, which may otherwise be filtered in renal glomerula, precipitate in the acidic lumen of renal tubules, occlude nephrons and thus trigger renal failure [59].

The stimulation of eryptosis were expected to foster development of anemia, as phosphatidylserine exposing erythrocytes are rapidly cleared from circulating blood. Anemia develops as soon as the loss of erythrocytes outcasts the formation of new erythrocytes by erythropoiesis [18]. Accordingly, side effects of NSC-95397 treatment may include anemia. The risk of anemia may be enhanced in several clinical conditions with enhanced susceptibility of erythrocytes to eryptosis, including iron deficiency [18], dehydration [60], hyperphosphatemia [61], chronic kidney disease (CKD) [62-65], hemolytic-uremic syndrome [66], diabetes [67], hepatic failure [36], malignancy [18], sepsis [68], sickle-cell disease [18], beta-thalassemia [18], Hb-C and G6PD-deficiency [18], as well as Wilsons disease [69]. The adherence of phosphatidylserine exposing erythrocytes to the vascular wall [70] and the stimulation of blood clotting may trigger thrombosis [71-73] and impair microcirculation $[20,71,74-77]$. The anemia and impairment of microcirculation may, at lest in theory, limit the use of the drug.

In conclusion, NSC-95397 triggers eryptosis with cell shrinkage and cell membrane scrambling, an effect in part due to $\mathrm{Ca}^{2+}$ entry, oxidative stress, ceramide and presumably activation of protein kinase $\mathrm{C}$.

\section{Acknowledgements}

The authors acknowledge the meticulous preparation of the manuscript by Tanja Loch. The study was supported by the Deutsche Forschungsgemeinschaft and Open Access Publishing Fund of Tuebingen University.

\section{Disclosure Statement}

None.

\section{References}

1 Boutros R, Dozier C, Ducommun B: The when and wheres of CDC25 phosphatases. Curr Opin Cell Biol 2006;18:185-191.

2 Han Y, Shen H, Carr BI, Wipf P, Lazo JS, Pan SS: NAD(P)H:quinone oxidoreductase-1-dependent and -independent cytotoxicity of potent quinone Cdc25 phosphatase inhibitors. J Pharmacol Exp Ther 2004;309:64-70.

3 Ko S, Lee W, Lee S, Park H: Nanosecond molecular dynamics simulations of Cdc25B and its complex with a 1,4-naphthoquinone inhibitor: implications for rational inhibitor design. J Mol Graph Model 2008;27:1319.

4 Lazo JS, Nemoto K, Pestell KE, Cooley K, Southwick EC, Mitchell DA, Furey W, Gussio R, Zaharevitz DW, Joo B, Wipf P: Identification of a potent and selective pharmacophore for Cdc25 dual specificity phosphatase inhibitors. Mol Pharmacol 2002;61:720-728.

5 Melchheier I, von Montfort C, Stuhlmann D, Sies H, Klotz LO: Quinone-induced Cdc25A inhibition causes ERK-dependent connexin phosphorylation. Biochem Biophys Res Commun 2005;327:1016-1023. 


\section{Cellular Physiology Cell Physiol Biochem 2016;40:597-607 and BiOChemistry \begin{tabular}{l|l} 
DOI: 10.1159/000452573 & (c) 2016 The Author(s). Published by S. Karger AG, Basel \\
www.karger.com/cpb
\end{tabular} \\ Jemaà et al.: NSC-95397-Induced Eryptosis}

6 Nemoto K, Vogt A, Oguri T, Lazo JS: Activation of the Raf-1/MEK/Erk kinase pathway by a novel Cdc25 inhibitor in human prostate cancer cells. Prostate 2004;58:95-102.

7 Park H, Carr BI, Li M, Ham SW: Fluorinated NSC as a Cdc25 inhibitor. Bioorg Med Chem Lett 2007;17:23512354.

8 Peyregne VP, Kar S, Ham SW, Wang M, Wang Z, Carr BI: Novel hydroxyl naphthoquinones with potent Cdc25 antagonizing and growth inhibitory properties. Mol Cancer Ther 2005;4:595-602.

9 Vogt A, McDonald PR, Tamewitz A, Sikorski RP, Wipf P, Skoko JJ, 3rd, Lazo JS: A cell-active inhibitor of mitogen-activated protein kinase phosphatases restores paclitaxel-induced apoptosis in dexamethasoneprotected cancer cells. Mol Cancer Ther 2008;7:330-340.

10 Yang Y, Yang WS, Yu T, Yi YS, Park JG, Jeong D, Kim JH, Oh JS, Yoon K, Kim JH, Cho JY: Novel antiinflammatory function of NSC95397 by the suppression of multiple kinases. Biochem Pharmacol 2014;88:201-215.

11 Dulyaninova NG, Hite KM, Zencheck WD, Scudiero DA, Almo SC, Shoemaker RH, Bresnick AR: Cysteine 81 is critical for the interaction of S100A4 and myosin-IIA. Biochemistry 2011;50:7218-7227.

12 Liu T, Li Y, Lin K, Yin H, He B, Zheng M, Wang G: Regulation of S100A4 expression via the JAK2-STAT3 pathway in rhomboid-phenotype pulmonary arterial smooth muscle cells exposure to hypoxia. Int J Biochem Cell Biol 2012;44:1337-1345.

13 Blevins MA, Kouznetsova J, Krueger AB, King R, Griner LM, Hu X, Southall N, Marugan JJ, Zhang Q, Ferrer M, Zhao R: Small Molecule, NSC95397, Inhibits the CtBP1-Protein Partner Interaction and CtBP1-Mediated Transcriptional Repression. J Biomol Screen 2015;20:663-672.

14 Perwitasari O, Torrecilhas AC, Yan X, Johnson S, White C, Tompkins SM, Tripp RA: Targeting cell division cycle 25 homolog B to regulate influenza virus replication. J Virol 2013;87:13775-13784.

15 Niisato N, Ohta M, Eaton DC, Marunaka Y: Hypotonic stress upregulates beta- and gamma-ENaC expression through suppression of ERK by inducing MKP-1. Am J Physiol Renal Physiol 2012;303:F240-252.

16 Larsson DE, Hassan S, Larsson R, Oberg K, Granberg D: Combination analyses of anti-cancer drugs on human neuroendocrine tumor cell lines. Cancer Chemother Pharmacol 2009;65:5-12.

17 Larsson DE, Wickstrom M, Hassan S, Oberg K, Granberg D: The cytotoxic agents NSC-95397, brefeldin A, bortezomib and sanguinarine induce apoptosis in neuroendocrine tumors in vitro. Anticancer Res 2010;30:149-156.

18 Lang E, Lang F: Mechanisms and pathophysiological significance of eryptosis, the suicidal erythrocyte death. Semin Cell Dev Biol 2015;39:35-42.

19 Lang PA, Kaiser S, Myssina S, Wieder T, Lang F, Huber SM: Role of Ca2+-activated K+ channels in human erythrocyte apoptosis. Am J Physiol Cell Physiol 2003;285:C1553-C1560.

20 Abed M, Towhid ST, Mia S, Pakladok T, Alesutan I, Borst O, Gawaz M, Gulbins E, Lang F: Sphingomyelinaseinduced adhesion of eryptotic erythrocytes to endothelial cells. Am J Physiol Cell Physiol 2012;303:C991999.

21 Lau IP, Chen H, Wang J, Ong HC, Leung KC, Ho HP, Kong SK: In vitro effect of CTAB- and PEG-coated gold nanorods on the induction of eryptosis/erythroptosis in human erythrocytes. Nanotoxicology 2012;6:847856.

22 Maellaro E, Leoncini S, Moretti D, Del Bello B, Tanganelli I, De Felice C, Ciccoli L: Erythrocyte caspase-3 activation and oxidative imbalance in erythrocytes and in plasma of type 2 diabetic patients. Acta Diabetol 2013;50:489-495.

23 Alzoubi K, Calabro S, Bissinger R, Abed M, Faggio C, Lang F: Stimulation of suicidal erythrocyte death by artesunate. Cell Physiol Biochem 2014;34:2232-2244.

24 Alzoubi K, Egler J, Abed M, Lang F: Enhanced Eryptosis Following Auranofin Exposure. Cell Physiol Biochem 2015;37:1018-1028.

25 Arnold M, Bissinger R, Lang F: Mitoxantrone-induced suicidal erythrocyte death. Cell Physiol Biochem 2014;34:1756-1767.

26 Arnold M, Lang E, Modicano P, Bissinger R, Faggio C, Abed M, Lang F: Effect of nitazoxanide on erythrocytes. Basic Clin Pharmacol Toxicol 2014;114:421-426.

27 Bissinger R, Barking S, Alzoubi K, Liu G, Liu G, Lang F: Stimulation of Suicidal Erythrocyte Death by the Antimalarial Drug Mefloquine. Cell Physiol Biochem 2015;36:1395-1405.

28 Bissinger R, Bouguerra G, Al Mamun Bhuyan A, Waibel S, Abbes S, Lang F: Efavirenz Induced Suicidal Death of Human Erythrocytes. Cell Physiol Biochem 2015;37:2496-2507.

29 Bissinger R, Fischer S, Jilani K, Lang F: Stimulation of Erythrocyte Death by Phloretin. Cell Physiol Biochem 2014;34:2256-2265. 


\section{Cellular Physiology Cell Physiol Biochem 2016;40:597-607 \begin{tabular}{l|l|l} 
DOI: 10.1159/000452573 & $\begin{array}{l}\text { C } 2016 \text { The Author(s). Published by S. Karger AG, Basel } \\
\text { www.karger.com/cpb }\end{array}$
\end{tabular} \\ Jemaà et al.: NSC-95397-Induced Eryptosis}

30 Bouguerra G, Aljanadi O, Bissinger R, Abbes S, Lang F: Embelin-Induced Phosphatidylserine Translocation in the Erythrocyte Cell Membrane. Cell Physiol Biochem 2015;37:1629-1640.

31 Bissinger R, Waibel S, Bouguerra G, Al Mamun Bhuyan A, Abbes S, Lang F: Enhanced Eryptosis Following Exposure to Lopinavir. Cell Physiol Biochem 2015;37:2486-2495.

32 Bouguerra G, Bissinger R, Abbes S, Lang F: Zopolrestat Induced Suicidal Death of Human Erythrocytes. Cell Physiol Biochem 2015;37:1537-1546.

33 Briglia M, Fazio A, Faggio C, Laufer S, Alzoubi K, Lang F: Triggering of Suicidal Erythrocyte Death by Ruxolitinib. Cell Physiol Biochem 2015;37:768-778.

34 Briglia M, Fazio A, Signoretto E, Faggio C, Lang F: Edelfosine Induced Suicidal Death of Human Erythrocytes. Cell Physiol Biochem 2015;37:2221-2230.

35 Calabro S, Alzoubi K, Faggio C, Laufer S, Lang F: Triggering of Suicidal Erythrocyte Death Following Boswellic Acid Exposure. Cell Physiol Biochem 2015;37:131-142.

36 Egler J, Lang F: Licochalcone A Induced Suicidal Death of Human Erythrocytes. Cell Physiol Biochem 2015;37:2060-2070.

37 Briglia M, Fazio A, Faggio C, Lang F: Triggering of Suicidal Erythrocyte Death by Zosuquidar. Cell Physiol Biochem 2015;37:2355-2365.

38 Jacobi J, Lang E, Bissinger R, Frauenfeld L, Modicano P, Faggio C, Abed M, Lang F: Stimulation of erythrocyte cell membrane scrambling by mitotane. Cell Physiol Biochem 2014;33:1516-1526.

39 Lang E, Zelenak C, Eberhard M, Bissinger R, Rotte A, Ghashghaeinia M, Lupescu A, Lang F, Qadri SM: Impact of Cyclin-Dependent Kinase CDK4 Inhibition on Eryptosis. Cell Physiol Biochem 2015;37:1178-1186.

40 Lupescu A, Bissinger R, Goebel T, Salker MS, Alzoubi K, Liu G, Chirigiu L, Mack AF, Qadri SM, Lang F: Enhanced suicidal erythrocyte death contributing to anemia in the elderly. Cell Physiol Biochem 2015;36:773-783.

41 Lupescu A, Bissinger R, Herrmann T, Oswald G, Jilani K, Lang F: Induction of suicidal erythrocyte death by novobiocin. Cell Physiol Biochem 2014;33:670-680.

42 Lupescu A, Bissinger R, Warsi J, Jilani K, Lang F: Stimulation of erythrocyte cell membrane scrambling by gedunin. Cell Physiol Biochem 2014;33:1838-1848.

43 Malik A, Bissinger R, Calabro S, Faggio C, Jilani K, Lang F: Aristolochic Acid Induced Suicidal Erythrocyte Death. Kidney Blood Press Res 2014;39:408-419.

44 Officioso A, Alzoubi K, Manna C, Lang F: Clofazimine Induced Suicidal Death of Human Erythrocytes. Cell Physiol Biochem 2015;37:331-341.

45 Oswald G, Alzoubi K, Abed M, Lang F: Stimulation of suicidal erythrocyte death by ribavirin. Basic Clin Pharmacol Toxicol 2014;114:311-317.

46 Peter T, Bissinger R, Enkel S, Alzoubi K, Oswald G, Lang F: Programmed erythrocyte death following in vitro Treosulfan treatment. Cell Physiol Biochem 2015;35:1372-1380.

47 Stockinger K, Bissinger R, Bouguerra G, Abbes S, Lang F: Enhanced Eryptosis Following Exposure to Carnosic Acid. Cell Physiol Biochem 2015;37:1779-1791.

48 Tesoriere L, Attanzio A, Allegra M, Cilla A, Gentile C, Livrea MA: Oxysterol mixture in hypercholesterolemiarelevant proportion causes oxidative stress-dependent eryptosis. Cell Physiol Biochem 2014;34:1075-1089.

49 Waibel S, Bissinger R, Bouguerra G, Abbes S, Lang F: Saquinavir Induced Suicidal Death of Human Erythrocytes. Cell Physiol Biochem 2015;37:1973-1982.

50 Zierle J, Bissinger R, Egler J, Lang F: Lapatinib Induced Suicidal Death of Human Erythrocytes. Cell Physiol Biochem 2015;37:2275-2287.

51 Briglia M, Calabro S, Signoretto E, Alzoubi K, Laufer S, Faggio C, Lang F: Fucoxanthin Induced Suicidal Death of Human Erythrocytes. Cell Physiol Biochem 2015;37:2464-2475.

52 Fazio A, Briglia M, Faggio C, Alzoubi K, Lang F: Oxaliplatin Induced Suicidal Death of Human Erythrocytes. Cell Physiol Biochem 2015;37:2393-2404.

53 Macczak A, Cyrkler M, Bukowska B, Michalowicz J: Eryptosis-inducing activity of bisphenol A and its analogs in human red blood cells (in vitro study). J Hazard Mater 2016;307:328-335.

54 Officioso A, Alzoubi K, Lang F, Manna C: Hydroxytyrosol inhibits phosphatidylserine exposure and suicidal death induced by mercury in human erythrocytes: Possible involvement of the glutathione pathway. Food Chem Toxicol 2016;89:47-53.

55 Officioso A, Manna C, Alzoubi K, Lang F: Bromfenvinphos induced suicidal death of human erythrocytes. Pestic Biochem Physiol 2016;126:58-63.

56 Qadri SM, Donkor DA, Bhakta V, Eltringham-Smith LJ, Dwivedi DJ, Moore JC, Pepler L, Ivetic N, Nazi I, FoxRobichaud AE, Liaw PC, Sheffield WP: Phosphatidylserine externalization and procoagulant activation 


\section{Cellular Physiology Cell Physiol Biochem 2016;40:597-607 \begin{tabular}{l|l|l} 
and Biochemistry Published online: November 25, 2016 & $\begin{array}{l}\text { C } 2016 \text { The Author(s). Published by S. Karger AG, Basel } \\
\text { www.karger.com/cpb }\end{array}$
\end{tabular} \\ Jemaà et al.: NSC-95397-Induced Eryptosis}

of erythrocytes induced by Pseudomonas aeruginosa virulence factor pyocyanin. J Cell Mol Med 2016;10.1111/jcmm.12778

57 Zierle J, Bissinger R, Bouguerra G, Abbes S, Lang F: Triggering of Suicidal Erythrocyte Death by Regorafenib. Cell Physiol Biochem 2016;38:160-172.

58 Pagano M, Faggio C: The use of erythrocyte fragility to assess xenobiotic cytotoxicity. Cell Biochem Funct 2015;33:351-355.

59 Harrison HE, Bunting H, Ordway NK, Albrink WS: The Pathogenesis of the Renal Injury Produced in the Dog by Hemoglobin or Methemoglobin. J Exp Med 1947;86:339-356.

60 Abed M, Feger M, Alzoubi K, Pakladok T, Frauenfeld L, Geiger C, Towhid ST, Lang F: Sensitization of erythrocytes to suicidal erythrocyte death following water deprivation. Kidney Blood Press Res 2013;37:567-578.

61 Voelkl J, Alzoubi K, Mamar AK, Ahmed MS, Abed M, Lang F: Stimulation of suicidal erythrocyte death by increased extracellular phosphate concentrations. Kidney Blood Press Res 2013;38:42-51.

62 Abed M, Artunc F, Alzoubi K, Honisch S, Baumann D, Foller M, Lang F: Suicidal erythrocyte death in endstage renal disease. J Mol Med (Berl) 2014;92:871-879.

63 Ahmed MS, Langer H, Abed M, Voelkl J, Lang F: The uremic toxin acrolein promotes suicidal erythrocyte death. Kidney Blood Press Res 2013;37:158-167.

64 Polak-Jonkisz D, Purzyc L: Ca(2+) influx versus efflux during eryptosis in uremic erythrocytes. Blood Purif 2012;34:209-210; author reply 210.

65 Calderon-Salinas JV, Munoz-Reyes EG, Guerrero-Romero JF, Rodriguez-Moran M, Bracho-Riquelme RL, Carrera-Gracia MA, Quintanar-Escorza MA: Eryptosis and oxidative damage in type 2 diabetic mellitus patients with chronic kidney disease. Mol Cell Biochem 2011;357:171-179.

66 Lang PA, Beringer O, Nicolay JP, Amon O, Kempe DS, Hermle T, Attanasio P, Akel A, Schafer R, Friedrich B, Risler T, Baur M, Olbricht CJ, Zimmerhackl LB, Zipfel PF, Wieder T, Lang F: Suicidal death of erythrocytes in recurrent hemolytic uremic syndrome. J Mol Med (Berl) 2006;84:378-388.

67 Nicolay JP, Schneider J, Niemoeller OM, Artunc F, Portero-Otin M, Haik G, Jr., Thornalley PJ, Schleicher E, Wieder T, Lang F: Stimulation of suicidal erythrocyte death by methylglyoxal. Cell Physiol Biochem 2006;18:223-232.

68 Kempe DS, Akel A, Lang PA, Hermle T, Biswas R, Muresanu J, Friedrich B, Dreischer P, Wolz C, Schumacher U, Peschel A, Gotz F, Doring G, Wieder T, Gulbins E, Lang F: Suicidal erythrocyte death in sepsis. J Mol Med (Berl) 2007;85:273-281.

69 Lang PA, Schenck M, Nicolay JP, Becker JU, Kempe DS, Lupescu A, Koka S, Eisele K, Klarl BA, Rubben H, Schmid KW, Mann K, Hildenbrand S, Hefter H, Huber SM, Wieder T, Erhardt A, Haussinger D, Gulbins E, Lang F: Liver cell death and anemia in Wilson disease involve acid sphingomyelinase and ceramide. Nat Med 2007;13:164-170.

70 Borst O, Abed M, Alesutan I, Towhid ST, Qadri SM, Foller M, Gawaz M, Lang F: Dynamic adhesion of eryptotic erythrocytes to endothelial cells via CXCL16/SR-PSOX. Am J Physiol Cell Physiol 2012;302:C644-C651.

71 Andrews DA, Low PS: Role of red blood cells in thrombosis. Curr Opin Hematol 1999;6:76-82.

72 Chung SM, Bae ON, Lim KM, Noh JY, Lee MY, Jung YS, Chung JH: Lysophosphatidic acid induces thrombogenic activity through phosphatidylserine exposure and procoagulant microvesicle generation in human erythrocytes. Arterioscler Thromb Vasc Biol 2007;27:414-421.

73 Zwaal RF, Comfurius P, Bevers EM: Surface exposure of phosphatidylserine in pathological cells. Cell Mol Life Sci 2005;62:971-988.

74 Closse C, Dachary-Prigent J, Boisseau MR: Phosphatidylserine-related adhesion of human erythrocytes to vascular endothelium. Br J Haematol 1999;107:300-302.

75 Gallagher PG, Chang SH, Rettig MP, Neely JE, Hillery CA, Smith BD, Low PS: Altered erythrocyte endothelial adherence and membrane phospholipid asymmetry in hereditary hydrocytosis. Blood 2003;101:46254627.

76 Pandolfi A, Di Pietro N, Sirolli V, Giardinelli A, Di Silvestre S, Amoroso L, Di Tomo P, Capani F, Consoli A, Bonomini M: Mechanisms of uremic erythrocyte-induced adhesion of human monocytes to cultured endothelial cells. J Cell Physiol 2007;213:699-709.

77 Wood BL, Gibson DF, Tait JF: Increased erythrocyte phosphatidylserine exposure in sickle cell disease: flowcytometric measurement and clinical associations. Blood 1996;88:1873-1880. 